\title{
Combined Effects of Auxin Application and Beneficial Microorganisms on Rooting and Growth of Ficus benjamina L. Air-layers
}

\author{
Abdel-Rahman, S.S.A.; O.H.M. Ibrahim; G.T. Mousa and Hala B. Soliman \\ Department of Ornamental Plants and Landscape Gardening, Faculty of Agricul- \\ ture, Assiut University \\ Received on: $14 / 3 / 2019$ \\ Accepted for publication on: 19/3/2019
}

\begin{abstract}
:
This study was conducted to define the best auxin application method with or without the inoculation with beneficial microorganism (Bacillus subtilis and arbuscular mycorrhizal fungi "AMF") to improve rooting characteristics of $F$. benjamina air-layers. The treatments were arranged in a split-plot design. Seven combined treatments of auxin concentrations and application methods (control, 50 and 100 ppm IBA in rooting substrate, 1500 and 3000 ppm IBA by painting girdled zone, 1500 and 3000 ppm IBA in talc paste) were assigned to the main plots. The sub-plots comprehended the application of B. subtilis and arbuscular mycorrhizal fungi in addition to the control. Data recorded on air-layers performance exhibited significant variation among different application methods and concentrations of IBA compared with the control with clear superiority of applying IBA at 3000 ppm by painting girdled zone in enhancing rooting\%, number, length, fresh and dry weights of roots per rooted air-layer, as well as total contents of both carbohydrates and phenolics, and showed the shortest period required for root appearance. Similar trend was noticed regarding survival percentage, increment in plant height and number of leaves and shoots after detaching air-layers from mother plants. All root and growth characteristics showed significant increment when air-layers were treated with B. subtilis or AMF compared to the control with clear superiority of $B$. subtilis. The combined treatment of IBA at $3000 \mathrm{ppm}$ by painting girdled zone and $B$. subtilis recorded the highest rooting $(100 \%)$ and survival percentages $(100 \%)$ and the best root and growth characteristics. This treatment could be recommended for propagation of Ficus benjamina by air layering.
\end{abstract}

Keywords: Ficus benjamina, IBA, Bacillus subtilis, arbuscular mycorrhizal fungi, air layering.

\section{Introduction}

Ficus benjamina belonging to family Moraceae, is a very popular ornamental species widely used as a pot-plant and in landscape gardening. As it has a high export potential, it can be cultivated commercially for exportation thereby earning foreign exchange (Gamlath et al., 2010). So, it is necessary to find a suitable technique for propagation at large scale in short time. It can be successfully propagated by air layering because it is simple and more rapid method for producing large plants with high quality.

Auxins such as indole-3-butyric acid (IBA) is known as rootpromoting chemicals to accelerate root initiation and development, rooting percentage, number and quality of roots produced per cutting and the 
uniformity of rooting (Wiessman-Ben and Tchoundjeu, 2000), which is attributed to the stability of IBA and stimulation of the rooting process (Hartmann et al., 2014). In the same context, Nanda and Kochhar (1985) studied the application of root promoting substances during layering to get profuse rooting within a short time period and IBA has been found the most effective. In addition, a wide variety of auxin application methods have been reported (Blythe et al., 2007). The most frequently used methods include the quick application with a concentrated solution (Blythe et al., 2004 on Ficus benjamina), a talc powder application (Solanki et al., 1986 on Prosopis cineraria, Hagen 1990 on Prosopis chilensis and Kumar, 2011 on guava), a lanolin paste (Suryanarayana and Rao, 1984 on Punica granatum and Ficus carica) or as a mixture with the rooting substrate in dilute concentrations (Wells, 1986 on Mahonia aquifolium and Gilani et al., 2019 on guava).

Recently, root promotion on airlayered shoots has been demonstrated by the inoculation with beneficial microorganisms such as Plant Growth Promoting Rhizobacteria (PGPR) and Arbuscular Mycorrhizal Fungi (AMF) (Rinallo et al., 1999, AbdelRahman and El-Naggar, 2014 and Zenginbal and Demir, 2018). Previous studies have shown that bacteria in several genera (Bacillus, Agrobacterium, Pseudomonas and Azospirillum) can induce adventitious root formation (Rinallo et al., 1999, Abdel-Rahman and El-Dsouky, 2010, Kumar, 2011, and Chawla and Mehta, 2015). The inoculation of rooting substrate with AMF during cutting propagation has been reported to increase rooting in many woody plants (Scagel, 2001, Scagel, et al. 2003 and Fernades et al, 2019). Adventitious root promotion is attributed to stimulate the synthesis of phytohormones such as auxins, gibberellins and cytikinins, as well as polyphenolic compounds by these beneficial microorganisms (Barea and Azcon-Aguilar, 1982, Mitchell et al., 1986 and Goto, 1990).

However, studies comparing different auxin application methods and evaluating the relationship between beneficial microorganisms such as Bacillus subtilis and arbuscular mycorrhizal fungi (AMF) and airlayers treated with auxins are still scarce. Therefore, the present study aimed to improve rootability, root and vegetative characteristics as well as survival percentage of Ficus benjamina air-layers by using different application methods of auxins and inoculation with B. subtilis and AMF.

\section{Material and Methods}

The current investigation was conducted at the Floriculture Farm, Faculty of Agriculture, Assiut University, Egypt, during the 2016 and 2017 seasons to determine the effects of indole-3-butyric acid (IBA) and/or beneficial microorganisms (Bacillus subtilis and arbuscular mycorrhizal fungi "AMF") on rooting and survival percentages as well as root and growth characteristics of Ficus benjamina air-layers.

Active strains of Bacillus subtilis and arbuscular mycorrhizal fungi "AMF" (Glomus intraradices) were obtained from the Unit of Biofertilizers, Fac. Agric., Ain Shams Univ., Egypt. Bacterial suspension prepared 
of B. subtilis $\left(10^{8} \mathrm{CFU} / \mathrm{ml}\right)$ and $\mathrm{AMF}$ inoculum (2500 spores/1 ) were supplied to rooting substrate at a rate of $10 \mathrm{ml} /$ layer for each of them after girdling process of $F$. benjamina shoots.

Seven combined treatments of IBA concentrations and application methods; control, 50 and 100 ppm IBA in rooting substrate, 1500 and 3000 ppm IBA by painting girdled zone, 1500 and 3000 ppm IBA in talc paste were used for treating airlayers.

Selected mature shoots of $F$. benjamina were girdled by removing $2.0 \mathrm{~cm}$ ring of bark in the intermodal region, ca. $120 \mathrm{~cm}$ below the tip of shoot. The layering operation was done at the beginning of March for both seasons. Air-layers were treated with IBA and/or beneficial microorganisms. The girdling region was immediately covered with a rooting substrate (perlite and peat moss " $1: 1$ $\mathrm{v} / \mathrm{v}$ "). The rooting substrate was covered with transparent plastic bags and the both ends were secured firmly using gunny thread and then covered with aluminum foil. Air-layers in the control were treated with distilled water alone.

The experiment was laid out as a $7 \times 3$ factorial arranged in a splitplot design with three replicates. Seven combined treatments of IBA were assigned to the main plots. The sub-plots comprehended the inoculation with B. subtilis or AMF in addition to the control. Each sub-unit contained five air-layers. The air-layers were protected from any mechanical damage and loss of moisture.

All the air-layers were detached from mother plants two and half months after air layering, then dipped in water to remove adhering rooting substrate. Data were recorded on rooting percentage, number of days to emerge visual roots, number of roots, root length, fresh and dry weights of roots per rooted air-layer. After detaching the rooted layers from mother plants, they were planted in polyethylene bags filled with clay soil and were kept under plastic house conditions. Six months later, the increment in shoot length and number of leaves and shoots parameters per rooted layer as well as survival percentage were recorded.

At the time of detaching the airlayers from mother plants, the basal 2.5-3.0 $\mathrm{cm}$ portion of root zone was used for determining total carbohydrates, phenols and endogenous phytohormones. Some samples were oven-dried at $70^{\circ} \mathrm{C}$ for $48 \mathrm{~h}$ and ground to a fine powder then placed for chemical procedures. Total carbohydrates content was determined colorimetrically using anthrone sulphuric acid method described by Fales (1951). The total phenolic content was estimated colorimetrically by Folin-ciocalteau reagent (FCR) method (Maliauskas et al., 2004).

Endogenous phytohormones in tissues of layered shoots bases were analyzed using GC-MS (7890A5975B) Gas Chromatograph Mass equipped with a flame ionization detector for separation of phytohormones constituents. The chromatograph apparatus was fitted with capillary colum DB-5ms. The oven temperature was set at $40^{\circ} \mathrm{c}$ for $2 \mathrm{~min}$., then temperature program ramp increase with a rate of $10^{\circ} \mathrm{c} / \mathrm{min}$ to $150^{\circ}$ c for 3 min., then it was increased at 
the rate of $10^{\circ} \mathrm{c} / \mathrm{min}$ to $220^{\circ} \mathrm{c}$ for 6 min and then at $15^{\circ} \mathrm{c} / \mathrm{min}$ to $280^{\circ} \mathrm{c}$ for $15 \mathrm{~min}$ and finally the a post run was at $260^{\circ} \mathrm{c}$ for $2 \mathrm{~min}$. Flow rates of gases was $0.5 \mathrm{~mL} / \mathrm{min}$ for $10.9 \mathrm{~min}$ then $1 \mathrm{~mL} / \mathrm{min}$ for $30 \mathrm{~min}$. Detector and injector temperatures were $300^{\circ}$ $\mathrm{C}$ and $260^{\circ} \mathrm{C}$, respectively. Hence, the total run time was $48 \mathrm{~min}$. The obtained chromatogram and report of GC Mass analysis for each sample were analyzed to calculate the percentage of main components of phytohormones (indole acetic acid and its derivatives, zeatin and gibberellic acid).

Data obtained were statistically analyzed using Statistix 8.1 analytical software and the means were compared using a least significant difference (L.S.D.) test based on Gomez and Gomez (1984).

\section{Results and Discussion Rooting percentage}

Results in Table 1 indicated that applying IBA by painting girdled zone was superior to the other application methods, followed by using IBA in the talc paste while application of IBA into the rooting substrate recorded lower results compared to the other methods. Besides, exogenous application of IBA at different concentrations significantly increased the rooting percentage of layered shoots compared to the control. The highest rooting percentages (91.1\%) were obtained from treated air-layers with 3000 ppm IBA by painting girdled zone. Similar results were obtained by Puri and Nagpal (1988) on Carissa carandas and Dalbergia sissoo, Dessalegn and Reddy (2003) on Simmondsia chinensis, Suresh et al. (2016) on Syzigium jambos, Chauhan (2009) and Reddy et al. (2014) in Ficus carica, Udhavrao (2017) on $\mathrm{Pu}$ nica granatum and Gilani et al. (2019) on Psidium guajava. These previous studies indicated that the increase in rooting percentage might be attributed to the vital role of higher IBA concentration in mobilization and utilization of carbohydrates and nitrogen fraction with the presence of co-factor at girdled zone which may have helped in better root initiation. Hence, IBA at higher concentration resulted in better rooting in $F$. benjamina air-layers. 
Table 1. Percentage of rooted layers in Ficus benjamina as affected by IBA treatments and beneficial microorganisms during the 2016 and 2017 seasons.

\begin{tabular}{|c|c|c|c|c|c|c|c|c|c|}
\hline \multirow{3}{*}{\multicolumn{2}{|c|}{\begin{tabular}{|c|} 
IBA \\
application methods \\
"ppm"
\end{tabular}}} & \multicolumn{8}{|c|}{ Beneficial microorganisms } \\
\hline & & \multicolumn{4}{|c|}{ First season (2016) } & \multicolumn{4}{|c|}{ Second season (2017) } \\
\hline & & Cont. & Bacillus & AMF & Mean & Cont. & Bacillus & $\mathbf{A M F}$ & Mean \\
\hline \multicolumn{2}{|c|}{ Control (non-treated) } & 53.33 & 66.67 & 60.00 & 60.00 & 53.33 & 66.67 & 66.67 & 62.22 \\
\hline \multirow{2}{*}{ in the substrate } & 50 & 66.67 & 80.00 & 73.33 & 73.33 & 66.67 & 80.00 & 73.33 & 73.33 \\
\hline & 100 & 73.33 & 80.00 & 80.00 & 77.78 & 66.67 & 86.67 & 80.00 & 77.78 \\
\hline \multirow{2}{*}{ by painting } & 1500 & 73.33 & 86.67 & 86.67 & 82.22 & 73.33 & 93.33 & 86.67 & 84.44 \\
\hline & 3000 & 80.00 & 100.00 & 100.00 & 93.33 & 80.00 & 100.00 & 86.67 & 88.89 \\
\hline \multirow{2}{*}{ Talc paste } & 1500 & 73.33 & 86.67 & 80.00 & 80.00 & 73.33 & 86.67 & 80.00 & 80.00 \\
\hline & 3000 & 80.00 & 93.33 & 93.33 & 88.89 & 73.33 & 93.33 & 86.67 & 84.44 \\
\hline \multicolumn{2}{|l|}{ Mean } & 71.43 & 84.76 & 81.90 & & 69.52 & 86.67 & 80.00 & \\
\hline \multicolumn{10}{|l|}{ LSD at 0.05} \\
\hline \multicolumn{2}{|l|}{ IBA Treatments } & \multicolumn{4}{|c|}{1.98} & \multicolumn{4}{|c|}{3.18} \\
\hline \multicolumn{2}{|l|}{ Microorganisms } & \multicolumn{4}{|c|}{1.38} & \multicolumn{4}{|c|}{1.78} \\
\hline \multicolumn{2}{|l|}{ Interaction } & \multicolumn{4}{|c|}{3.65} & \multicolumn{4}{|c|}{4.71} \\
\hline
\end{tabular}

On the other hand, inoculation with B. subtilis and AMF significantly increased rooting percentage comparing with the untreated layers (control). Bacillus subtilis treatment was more effective on stimulating adventitious root formation $(85.8 \%)$ than AMF treatment $(81.0 \%)$ as average of two seasons, respectively. These results agree with those obtained by Rinallo et al. (1999), Abdel-Rahman and El-Dsouky (2010) and Kumar (2011). Also, Chawla and Mehta (2015) stated that PGPR increased adventitious roots formation. PGPR encouraged beneficial effect on plant growth and accelerate the availability of nutrients and assimilate and well as the production of phytohormones. It has been reported that B. subtilis produces IAA (Goto, 1990 and Rajan and Radhakrishna, 2013).

The interaction effect between IBA application methods and beneficial microorganisms was significant during both seasons. Rooting percentage reached $100 \%$ in air-layers treated with both IBA at 3000 ppm by painting girdled zone and $B$. subtilis in both seasons. When AMF com- bined with the same IBA treatment, rooting percentage reached $93.35 \%$ as average of both seasons. These results are in accordance with those obtained by Rinallo et al. (1999), Chawla (2011), Zenginbal and Demir (2018) and Fernades et al. (2019). The higher rooting percentage of $F$. benjamina air-layers may be due to synergistic effect of IBA in combination with B. subtilis or AMF (Rinallo, 1999, Scagel, et al., 2003, Kumar, 2011 and Abdel-Rahman and ElNaggar, 2014).

\section{Root characteristics}

The results presented in Tables $2,3,4,5$ and 6 revealed that all IBA treatments considerably induced early root appearance and improved root characteristics of air-layers. Among IBA treatments, IBA at 3000 ppm by painting girdled zone resulted in significant decrease in number of days required for roots appearance and was significantly superior over rest of the concentrations. This treatment also increased each of number and length of roots as well as fresh and dry weights of roots. These results are in agreement with those obtained by Suryanarayana and Rao (1984), Des- 
salegn and Reddy (2003), Chawla (2011), Reddy et al. (2014) and Gilani et al. (2019). They observed that treating air-layers with IBA accelerate root appearance and improve root characteristics. They added that the response of air-layers to increasing IBA concentrations might be due to the activity of auxin and the accumulation of rooting co-factors at cambial region above the ringed portion. Also, enhancement of auxin concentration in the cell that may be adequate for initiating root primordia early by increasing cell division that further speed up callus formation. Nanda (1975) ascribed the promotive effect of IBA to better utilization of reserved carbohydrates in the hardwood with the application of exogenous auxin by converting starch into simple sugars, which is required for the production of new cells and for increased respiratory activity in regenerating tissues at the time of root initiation. The increase in fresh and dry weights of roots may be due to exogenous application of auxin which generally stimulate the movement of natural auxin and other materials downward from the leaves and shoot tips and accumulate at the girdling zone resulted in root formation with higher fresh weight as reported by Maurya et al. (2012) and Baghel et al. (2016).

Regarding the effect of beneficial microorganisms, early root appearance and better root characteristics were obtained by inoculation of air-layers with $B$. subtilis or AMF comparing to the control with a remarked superiority to $B$. subtilis over AMF. These results are in accordance with those revealed by Rinallo et al.
(1999), Abdel-Rahman and ElNaggar (2014), Chawla and Mehta (2015) and Zenginbal and Demir (2018). Promotion of adventitious roots formation is attributed to the production of phytohormones such as auxins, gibberellins and cytokinins as well as polyphenolic compounds by these beneficial microorganisms (Barea and Azcon-Aguilar, 1982, Mitchell et al, 1986, Goto, 1990 and Erturk et al., 2010). It is well documented that AMF stimulates the biomass of the root system (Sarkar et al., 2015). This observation appeared that the increase in fresh and dry weights of roots of layered shoots in F. benjamina plants associated with AMF was due to the symbiosis between the roots of the host plants and the mycorrhizal fungi that resulted in an increase in nutrients and water uptake, thus favoring biomass production.

The combined effects of IBA application methods and beneficial microorganisms were significant and showed that early root appearance was obtained under $3000 \mathrm{ppm}$ IBA by painting girdled zone combined with $B$. subtilis treatment followed by 3000 ppm IBA by painting girdled zone + AMF which were remarkably superior to other treatments. It has previously been demonstrated that the combined treatment of the beneficial microorganisms and IBA showed greater capacity than IBA or microorganisms alone in accelerating and enhancing rooting in several plant species (Scagel et al., 2003, AbdelRahman and El-Naggar, 2014, Abdul Hakim et al., 2018 and Fernades et al., 2019). They attributed this effect to the synergistic influence since IBA is known for promoting emergence of 
roots when used at optimum concentration in combination with beneficial microorganisms. Fuscon (2014) has lately cleared the interactive role of auxin and arbuscular mycorrhizal fungi and their host during the precolonization phase as being important in the process of lateral root formation. In addition, this also enhances changes in the release of carbohydrates to the roots and modulation of phytohormones concentration resulting in improving root system (Schott et al., 2013).

Table 2. Number of days to emerge visual roots in Ficus benjamina air-layers as affected by IBA treatments and beneficial microorganisms during the 2016 and 2017 seasons.

\begin{tabular}{|c|c|c|c|c|c|c|c|c|c|}
\hline \multirow{3}{*}{\multicolumn{2}{|c|}{\begin{tabular}{|c|} 
IBA \\
application methods \\
"ppm"
\end{tabular}}} & \multicolumn{8}{|c|}{ Beneficial microorganisms } \\
\hline & & \multicolumn{4}{|c|}{ First season (2016) } & \multicolumn{4}{|c|}{ Second season (2017) } \\
\hline & & Cont. & Bacillus & AMF & Mean & Cont. & Bacillus & AMF & Mean \\
\hline \multicolumn{2}{|c|}{ Control (non-treated) } & 48.7 & 40.3 & 42.0 & 43.7 & 47.3 & 40.7 & 41.7 & 43.2 \\
\hline \multirow{2}{*}{ in the substrate } & 50 & 39.3 & 36.0 & 37.7 & 37.7 & 39.3 & 35.7 & 36.0 & 37.0 \\
\hline & 100 & 37.7 & 36.7 & 37.3 & 37.2 & 37.0 & 34.3 & 35.0 & 35.4 \\
\hline \multirow{2}{*}{ by painting } & 1500 & 37.7 & 36.3 & 36.7 & 36.9 & 34.7 & 34.0 & 35.0 & 34.6 \\
\hline & 3000 & 36.0 & 29.3 & 32.7 & 32.7 & 34.0 & 29.7 & 33.7 & 32.1 \\
\hline \multirow{2}{*}{ Talc paste } & 1500 & 37.0 & 35.3 & 35.7 & 36.0 & 33.7 & 35.7 & 35.3 & 34.9 \\
\hline & 3000 & 35.0 & 32.3 & 33.7 & 33.7 & 34.7 & 32.3 & 33.7 & 33.6 \\
\hline \multicolumn{2}{|l|}{ Mean } & 38.8 & 35.2 & 36.5 & & 37.2 & 34.6 & 35.6 & \\
\hline \multicolumn{10}{|l|}{ LSD at 0.05} \\
\hline \multicolumn{2}{|l|}{ IBA Treatments } & \multicolumn{4}{|c|}{0.7} & \multicolumn{4}{|c|}{0.9} \\
\hline \multicolumn{2}{|l|}{ Microorganisms } & \multicolumn{4}{|c|}{1.0} & \multicolumn{4}{|c|}{0.7} \\
\hline \multicolumn{2}{|l|}{ Interaction } & \multicolumn{4}{|c|}{2.6} & \multicolumn{4}{|c|}{1.8} \\
\hline
\end{tabular}

Table 3. Root number per air-layer of Ficus benjamina as affected by IBA treatments and beneficial microorganisms during the 2016 and 2017 seasons.

\begin{tabular}{|c|c|c|c|c|c|c|c|c|c|}
\hline \multirow{3}{*}{\multicolumn{2}{|c|}{$\begin{array}{c}\text { IBA } \\
\begin{array}{c}\text { application methods } \\
\text { "ppm" }\end{array} \\
\end{array}$}} & \multicolumn{8}{|c|}{ Beneficial microorganisms } \\
\hline & & \multicolumn{4}{|c|}{ First season (2016) } & \multicolumn{4}{|c|}{ Second season (2017) } \\
\hline & & Cont. & Bacillus & AMF & Mean & Cont. & Bacillus & AMF & Mean \\
\hline \multicolumn{2}{|c|}{ Control (non-treated) } & 6.67 & 15.33 & 13.33 & 11.78 & 7.00 & 17.67 & 15.67 & 13.44 \\
\hline \multirow{2}{*}{ In the substrate } & 50 & 20.83 & 25.67 & 24.50 & 23.67 & 19.83 & 32.50 & 27.83 & 26.72 \\
\hline & 100 & 23.17 & 29.17 & 27.37 & 26.57 & 21.17 & 38.33 & 36.67 & 32.06 \\
\hline \multirow{2}{*}{ By painting } & 1500 & 28.33 & 36.33 & 33.67 & 32.78 & 27.00 & 43.00 & 37.50 & 35.83 \\
\hline & 3000 & 30.83 & 40.33 & 36.33 & 35.83 & 38.50 & 49.00 & 47.67 & 45.06 \\
\hline \multirow{2}{*}{ Talc paste } & 1500 & 28.33 & 33.50 & 30.83 & 30.89 & 29.50 & 40.00 & 38.33 & 35.94 \\
\hline & 3000 & 28.33 & 37.00 & 35.67 & 33.67 & 31.00 & 43.00 & 40.00 & 38.00 \\
\hline \multicolumn{2}{|l|}{ Mean } & 23.79 & 31.05 & 28.81 & & 24.86 & 37.64 & 34.81 & \\
\hline \multicolumn{2}{|l|}{ LSD at 0.05} & & & & & & & & \\
\hline \multicolumn{2}{|l|}{ IBA Treatments } & \multicolumn{4}{|c|}{1.36} & \multicolumn{4}{|c|}{1.36} \\
\hline \multicolumn{2}{|l|}{ Microorganisms } & \multicolumn{4}{|c|}{0.68} & \multicolumn{4}{|c|}{1.04} \\
\hline \multicolumn{2}{|l|}{ Interaction } & \multicolumn{4}{|c|}{1.80} & \multicolumn{4}{|c|}{2.75} \\
\hline
\end{tabular}

Cont. $=$ control, AMF $=$ Arbuscular Mycorrhizal Fungi, Bacillus $=$ Bacillus subtilis 
Table 4. Root length (cm) per air-layer of Ficus benjamina as affected by IBA treatments and beneficial microorganisms during the 2016 and 2017 seasons.

\begin{tabular}{|c|c|c|c|c|c|c|c|c|c|}
\hline \multirow{3}{*}{\multicolumn{2}{|c|}{$\begin{array}{c}\text { IBA } \\
\text { application methods } \\
\text { "ppm" }\end{array}$}} & \multicolumn{8}{|c|}{ Beneficial microorganisms } \\
\hline & & \multicolumn{4}{|c|}{ First season (2016) } & \multicolumn{4}{|c|}{ Second season (2017) } \\
\hline & & Cont. & Bacillus & AMF & Mean & Cont. & Bacillus & AMF & Mean \\
\hline \multicolumn{2}{|c|}{ Control (non-treated) } & 6.83 & 13.17 & 11.33 & 10.44 & 12.17 & 19.67 & 18.33 & 16.72 \\
\hline \multirow{2}{*}{ In the substrate } & 50 & 10.60 & 14.17 & 13.33 & 12.70 & 16.33 & 22.67 & 21.67 & 20.22 \\
\hline & 100 & 12.67 & 13.17 & 14.33 & 13.39 & 19.00 & 24.50 & 16.00 & 19.83 \\
\hline \multirow{2}{*}{ By painting } & 1500 & 14.00 & 17.00 & 15.17 & 15.39 & 22.17 & 27.33 & 25.67 & 25.06 \\
\hline & 3000 & 16.67 & 20.00 & 19.00 & 18.56 & 24.50 & 29.00 & 28.83 & 27.44 \\
\hline \multirow{2}{*}{ Talc paste } & 1500 & 13.50 & 16.00 & 14.67 & 14.72 & 22.00 & 18.83 & 23.50 & 21.44 \\
\hline & 3000 & 14.33 & 16.83 & 16.17 & 15.78 & 23.00 & 20.33 & 26.33 & 23.22 \\
\hline \multicolumn{2}{|l|}{ Mean } & 12.66 & 15.76 & 14.86 & & 19.88 & 23.19 & 22.90 & \\
\hline \multicolumn{2}{|l|}{ LSD at 0.05} & & & & & & & & \\
\hline \multicolumn{2}{|l|}{ IBA Treatments } & \multicolumn{4}{|c|}{0.65} & \multicolumn{4}{|c|}{$\frac{1}{2.27}$} \\
\hline \multicolumn{2}{|l|}{ Microorganisms } & \multirow{2}{*}{\multicolumn{4}{|c|}{$\frac{0.54}{1.43}$}} & \multicolumn{4}{|c|}{1.35} \\
\hline \multicolumn{2}{|l|}{ Interaction } & & & & & \multicolumn{4}{|c|}{3.58} \\
\hline
\end{tabular}

Table 5. Root fresh weight (g/air-layer) of Ficus benjamina as affected by IBA treatments and beneficial microorganisms during the 2016 and 2017 seasons.

\begin{tabular}{|c|c|c|c|c|c|c|c|c|c|}
\hline \multirow{3}{*}{\multicolumn{2}{|c|}{$\begin{array}{c}\text { IBA } \\
\text { application methods } \\
\text { "ppm" }\end{array}$}} & \multicolumn{8}{|c|}{ Beneficial microorganisms } \\
\hline & & \multicolumn{4}{|c|}{ First season (2016) } & \multicolumn{4}{|c|}{ Second season (2017) } \\
\hline & & Cont. & Bacillus & AMF & Mean & Cont. & Bacillus & AMF & Mean \\
\hline \multicolumn{2}{|c|}{ Control (non-treated) } & 5.60 & 8.90 & 8.37 & 7.62 & 7.34 & 11.68 & 10.67 & 9.90 \\
\hline \multirow{2}{*}{ In the substrate } & 50 & 10.20 & 13.87 & 12.27 & 12.11 & 10.77 & 14.91 & 12.95 & 12.88 \\
\hline & 100 & 11.07 & 15.43 & 13.90 & 13.47 & 13.11 & 20.17 & 16.56 & 16.61 \\
\hline \multirow{2}{*}{ By painting } & 1500 & 14.27 & 21.17 & 18.67 & 18.03 & 18.84 & 23.87 & 22.33 & 21.68 \\
\hline & 3000 & 18.10 & 32.63 & 30.27 & 27.00 & 24.30 & 33.37 & 29.18 & 28.95 \\
\hline \multirow{2}{*}{ Talc paste } & 1500 & 12.37 & 20.73 & 17.03 & 16.71 & 17.37 & 20.65 & 19.52 & 19.18 \\
\hline & 3000 & 14.70 & 25.23 & 22.23 & 20.72 & 19.26 & 24.56 & 23.30 & 22.37 \\
\hline \multicolumn{2}{|l|}{ Mean } & 12.33 & 19.71 & 17.53 & & 15.86 & 21.32 & 19.22 & \\
\hline \multicolumn{10}{|l|}{ LSD at 0.05} \\
\hline \multicolumn{2}{|l|}{ IBA Treatments } & \multicolumn{4}{|c|}{0.84} & \multicolumn{4}{|c|}{0.53} \\
\hline \multicolumn{2}{|l|}{ Microorganisms } & \multirow{2}{*}{\multicolumn{4}{|c|}{$\begin{array}{l}0.69 \\
183\end{array}$}} & \multicolumn{4}{|c|}{0.48} \\
\hline \multicolumn{2}{|l|}{ Interaction } & & & & & \multicolumn{4}{|c|}{1.27} \\
\hline
\end{tabular}

Cont. $=$ control, $\mathrm{AMF}=$ Arbuscular Mycorrhizal Fungi, Bacillus $=$ Bacillus subtilis

Table 6. Root dry weight (g/air-layer) of Ficus benjamina as affected by IBA treatments and beneficial microorganisms during the 2016 and 2017 seasons.

\begin{tabular}{|c|c|c|c|c|c|c|c|c|c|}
\hline \multirow{3}{*}{\multicolumn{2}{|c|}{$\begin{array}{c}\text { IBA } \\
\text { application methods } \\
\text { "ppm" }\end{array}$}} & \multicolumn{8}{|c|}{ Beneficial microorganisms } \\
\hline & & \multicolumn{4}{|c|}{ First season (2016) } & \multicolumn{4}{|c|}{ Second season (2017) } \\
\hline & & Cont. & Bacillus & AMF & Mean & Cont. & Bacillus & AMF & Mean \\
\hline \multicolumn{2}{|c|}{ Control (non-treated) } & 1.60 & 3.07 & 2.93 & 2.54 & 2.19 & 3.35 & 3.31 & 2.95 \\
\hline \multirow{2}{*}{ In the substrate } & 50 & 3.21 & 3.93 & 3.60 & 3.58 & 3.59 & 4.24 & 4.03 & 3.95 \\
\hline & 100 & 3.23 & 4.41 & 4.08 & 3.91 & 4.21 & 5.92 & 4.94 & 5.02 \\
\hline \multirow{2}{*}{ By painting } & 1500 & 4.12 & 5.94 & 5.00 & 5.02 & 5.74 & 6.59 & 6.09 & 6.14 \\
\hline & 3000 & 4.95 & 8.19 & 7.50 & 6.88 & 6.92 & 9.76 & 8.83 & 8.50 \\
\hline \multirow{2}{*}{ Talc paste } & 1500 & 3.48 & 5.21 & 4.48 & 4.39 & 4.68 & 5.80 & 5.71 & 5.40 \\
\hline & 3000 & 3.98 & 6.16 & 5.84 & 5.33 & 5.18 & 6.63 & 6.16 & 5.99 \\
\hline \multicolumn{2}{|l|}{ Mean } & 3.51 & 5.27 & 4.78 & & 4.64 & 6.04 & 5.58 & \\
\hline \multicolumn{10}{|l|}{ LSD at 0.05} \\
\hline \multicolumn{2}{|l|}{ IBA Treatments } & \multicolumn{4}{|c|}{0.66} & \multicolumn{4}{|c|}{0.48} \\
\hline \multicolumn{2}{|l|}{ Microorganisms } & \multicolumn{4}{|c|}{0.23} & \multicolumn{4}{|c|}{0.33} \\
\hline \multicolumn{2}{|l|}{ Interaction } & \multicolumn{4}{|c|}{0.62} & \multicolumn{4}{|c|}{ N.S. } \\
\hline
\end{tabular}

Cont. $=$ control, AMF $=$ Arbuscular Mycorrhizal Fungi, Bacillus $=$ Bacillus subtilis 
Vegetative growth characteristics

Data presented in Figures 1 and

2 show that treatment of $F$. benjamina air-layers with IBA and/or beneficial microorganisms significantly increased plant height and number of shoots and leaves per rooted layer at 6 months after transplanting compared to the control in both seasons. However, application of 3000 ppm IBA by painting girdled zone combined with $B$. subtilis was the most effective on increasing vegetative growth characteristics of rooted layers, followed by 3000 ppm IBA by painting girdled zone + AMF treatment comparing with the individual treatments of IBA or beneficial microorganisms. Since these separated layers are having better root system, they could absorb sufficient water and other nutrients, which could be excellent in all studied characters. These results are in agreement with the finding of Khalid et al. (2004), Chawla (2011) and Kumar (2011). In addition, Abdel-Rahman and ElDsouky (2010) and Abdel-Rahman and El-Naggar (2014) found that combined IBA-bacteria or IBA-AMF treatments were more effective in increasing root and vegetative growth then control or IBA and beneficial microorganisms alone.
The increment in vegetative growth characteristics as a results of IBA treatments may be due to the role of IBA on cell division and/or cell elongation (Noggle and Fritz, 1989). Besides, the stimulatory action of auxin in softening the cell wall, increasing its plasticity leading to cell enlargement of the protoplast by water uptake and consequently stimulating the growth (Tagwa and Bonner, 1957). The enhancing effect of $B$. subtilis on the vegetative growth characters obtained in the present investigation was also found by Karakurt et al. (2009) and Erturk et al. (2010).

The PGPR may increase the level of root hormone by production of IAA, cytokinin other plant hormones. Thus, the amount of IAA and cytokinin may appear to be directly correlated with plant growth. Many plant-associated bacteria have the ability to produce plant growth regulators especially IAA which further play an important role in plant growth promotion (Patten and Glick, 2002 and Khalid et al., 2004) and hence may have increased growth emergence after transplanting. 


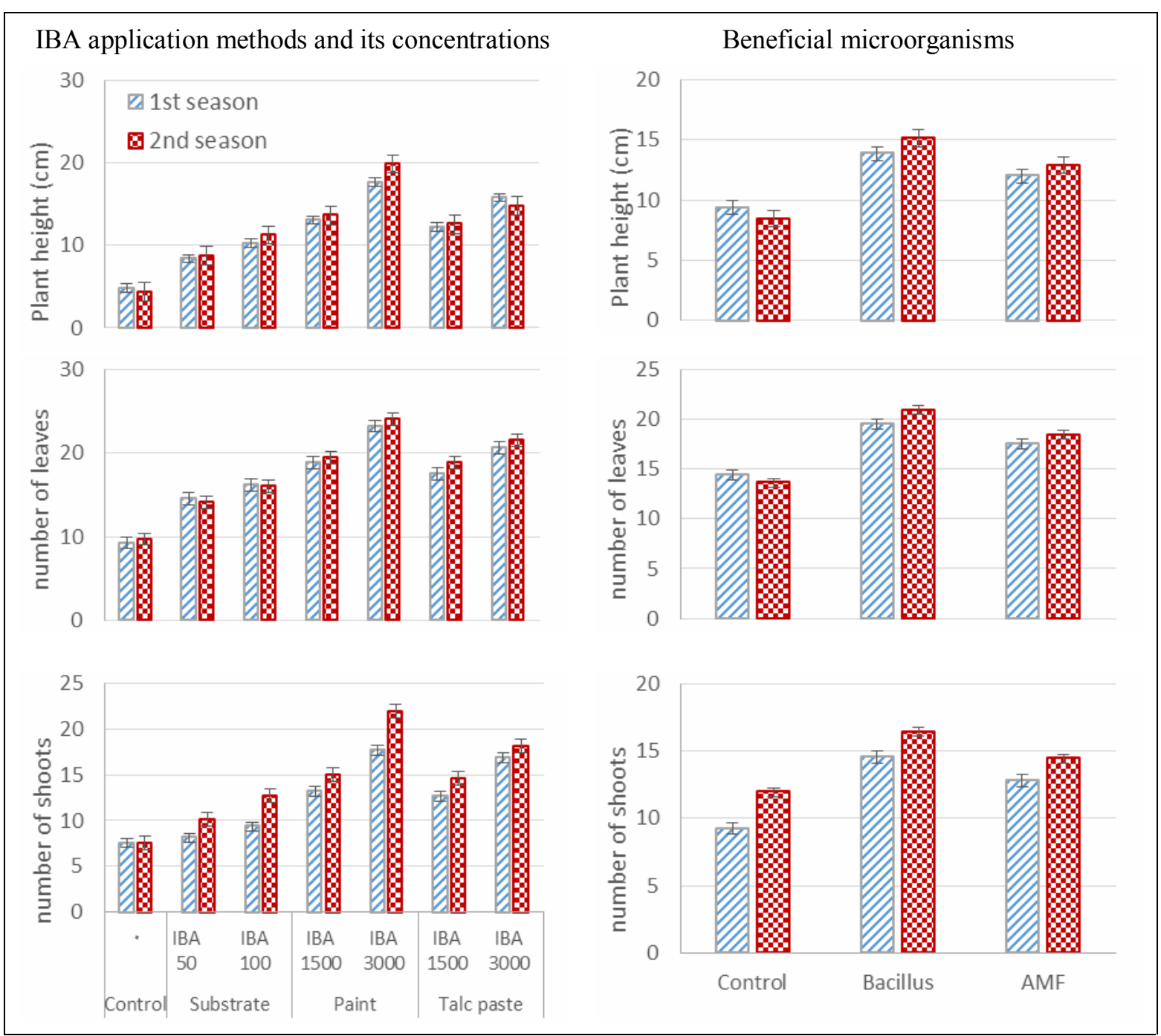

Fig. 1. Effect of IBA at different concentrations and application methods, and beneficial microorganisms on vegetative growth characteristics of $F$. benjamina during both seasons. Vertical bars above mean denote $\mathrm{LSD}$ values $(p \leq 0.05)$. 


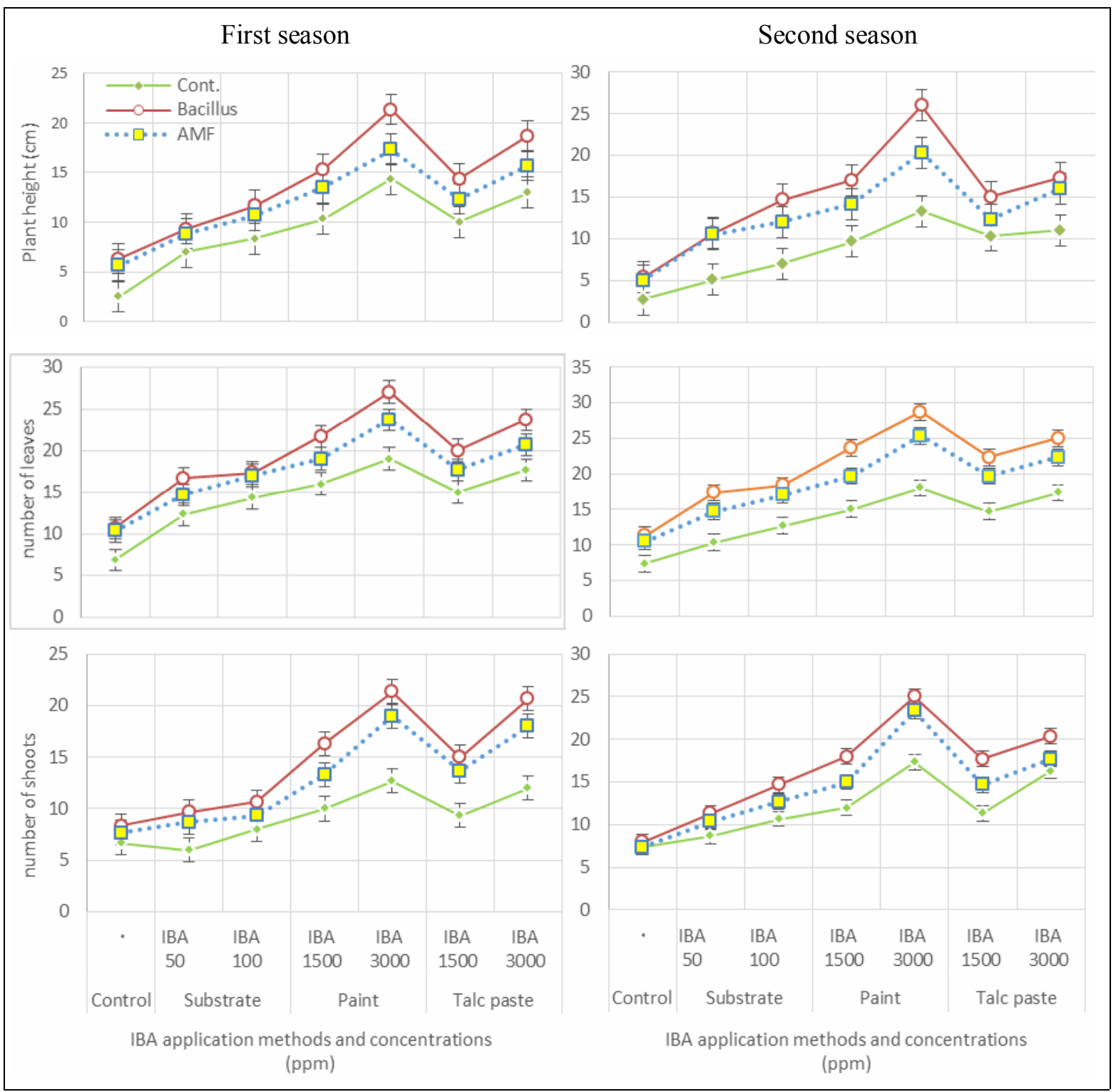

Fig. 2. Interaction effects between IBA at different concentrations and application methods and beneficial microorganisms on vegetative growth characteristics of $F$. benjamina during both seasons. Vertical bars above mean denote LSD values $(p \leq 0.05)$.

\section{Survival percentage}

Survival percentage of successfully rooted air-layers is almost important characteristic which has to be carefully traced when propagating plants by air-layering. This is logic since attaining successful rooting with extra root characteristic has no value without successfully survive these air-layers. Accordingly, data on survival percentage of $F$. benjamina air-layers were represented in Table
7. It could be inferred that treating air-layers of $F$. benjamina with IBA at 3000 ppm by painting girdled zone combined with Bacillus or AMF which produced the best rooting characteristics seem to influence the survival percentage as well. These combined treatments gave the maximum survival percentage $(100 \%)$ in both seasons comparing to untreated layers $(53.7 \%)$ as an average of two seasons. These results are in concur- 
rence with the findings of Singh et al. (2007), Kumar (2011) and Baghel et al. (2016). The higher percentage of survival after transplanting the rooted air-layers can be attributed to the possession of better root characteristics like higher number and length of roots (Kumar, 2011 and Reddy et al., 2014). In addition, it might be due to the rooting co-factors and their balance with nutritive substances and auxin (Rymbai and Reddy, 2010 and Baghel et al., 2016).

Beneficial microorganisms including bacteria and mycorrhizae fungi encourage plant growth and accelerate the availability of nutrients and assimilates, as well as the production of substances promoting plant growth. This effect happens through the biological nitrogen fixation, increasing inorganic phosphate solubilization of organic phosphorus compounds, as well as water and nutrient uptake (Esitken et al., 2003, Das et al., 2006, Aslantas et al., 2007 and Chawla, 2011) and hence improving survival percentage.

Table 7. Survival percentage of new produced plants after 6 months from transplanting in Ficus benjamina as affected by IBA treatments and beneficial microorganisms during the 2016 and 2017 seasons.

\begin{tabular}{|c|c|c|c|c|c|c|c|c|c|}
\hline \multirow{3}{*}{\multicolumn{2}{|c|}{$\begin{array}{c}\text { IBA } \\
\text { application methods } \\
\text { "ppm" }\end{array}$}} & \multicolumn{8}{|c|}{ Beneficial microorganisms } \\
\hline & & \multicolumn{4}{|c|}{ First season (2016) } & \multicolumn{4}{|c|}{ Second season (2017) } \\
\hline & & Cont. & Bacillus & AMF & Mean & Cont. & Bacillus & AMF & Mean \\
\hline \multicolumn{2}{|c|}{ Control (non-treated) } & 50.03 & 55.57 & 50.00 & 51.87 & 50.00 & 61.10 & 55.57 & 55.56 \\
\hline \multirow{2}{*}{ In the substrate } & 50 & 61.10 & 77.77 & 72.23 & 70.37 & 61.10 & 77.77 & 72.23 & 70.37 \\
\hline & 100 & 66.67 & 88.90 & 88.90 & 81.49 & 61.10 & 88.90 & 88.90 & 79.63 \\
\hline \multirow{2}{*}{ By painting } & 1500 & 72.23 & 80.57 & 77.80 & 76.87 & 72.23 & 88.90 & 77.80 & 79.64 \\
\hline & 3000 & 77.80 & 100.00 & 91.67 & 89.82 & 77.80 & 100.00 & 91.67 & 89.82 \\
\hline \multirow{2}{*}{ Talc paste } & 1500 & 66.67 & 77.80 & 77.80 & 74.09 & 66.67 & 77.80 & 77.80 & 74.09 \\
\hline & 3000 & 77.80 & 91.67 & 88.90 & 86.12 & 77.80 & 91.67 & 88.90 & 86.12 \\
\hline \multicolumn{2}{|l|}{ Mean } & 67.47 & 81.75 & 78.19 & & 66.67 & 83.73 & 78.98 & \\
\hline \multicolumn{2}{|l|}{ LSD at 0.05} & & & & & & & & \\
\hline \multicolumn{2}{|l|}{ IBA Treatments } & \multicolumn{4}{|c|}{4.40} & \multicolumn{4}{|c|}{4.27} \\
\hline \multicolumn{2}{|l|}{ Microorganisms } & \multirow{2}{*}{\multicolumn{4}{|c|}{$\frac{2.44}{6.47}$}} & \multicolumn{4}{|c|}{2.69} \\
\hline \multicolumn{2}{|l|}{ Interaction } & & & & & \multicolumn{4}{|c|}{7.11} \\
\hline
\end{tabular}

Cont. $=$ control, $\mathrm{AMF}=$ Arbuscular Mycorrhizal Fungi, Bacillus $=$ Bacillus subtilis

\section{Total carbohydrates and phenols content}

The obtained results (Tables 8 and 9) show that total carbohydrates and phenols contents were higher in the air-layers treated with IBA and/or beneficial microorganisms compared to untreated layers at the end of the rooting period. The air-layers treated with 3000 ppm IBA by painting girdled zone $+B$. subtilis contained higher levels of total carbohydrates and phenols which led to maximum rooting, followed by the combined treatment of 3000 ppm IBA + AMF. These results are in agreement with those obtained by Hess (1964), Yeboah et al. (2014) and Suresh et al. (2016). They stated that higher levels of total carbohydrates and phenols in plant tissues could stimulate adventitious root formation and improve root development. The present study indicate a positive relationship between rootability of $F$. benjamina air-layers treated with IBA combined with $B$. 
subtilis or AMF and carbohydrates and phenols content in basal parts of the layered shoots. These results could be attributed to certain evidences supported by the effective role of carbohydrates and phenols as well as production of IAA using $B$. subtilis and AMF in the presence of IBA to exert an effect on the rootability of air-layers.

As for phenols, several studies (Hess, 1962, Karunakara, 1997 and Kumar, 2011) showed that the phenolic compounds act as auxin co-factors in root promotion. The auxins such as applied IBA and IAA produced by beneficial microorganisms bound the phenol molecules and translocate them to the girdled zone to prevent infection of the developed roots, as well as serve as protection against the oxidation of the auxins by IAAoxidase (Pandey and Pathak, 1981 and Hartmann et al., 2014).

On the other hand, carbohydrates have most often been considered to be the principal source of energy and carbon during rooting proc- ess (Haissig, 1974). Carbohydrates concentration in plant tissues may be influenced by IBA treatment and beneficial microorganisms inoculation, which can enhance mobilization of carbohydrate in leaves and upper stem and increase transport to the rooting zone (Haissig, 1982, Woodward and Bartel, 2005 and AbdelRahman and El-Naggar, 2014). Several investigators (Abdel-Rahman and El-Dsouky, 2010, Kumar, 2011 and Kasem and Abd El-Baset, 2014) confirmed the importance of carbohydrates accumulation in plant tissues to improve number of roots and shoots. Arslonov (1979) observed breakdown of carbohydrates during the initial stages of root growth in lemon cuttings, and also noted a rise in catalase and peroxidase activities which accompanied by the breakdown of carbohydrates. The difference in the magnitude of decline of starch content between the treated and untreated layers showed that the exogenous application of auxins might have enhanced the hydrolysis of starch.

Table 8. Total carbohydrates (\%) in tissue of girdled zone in Ficus benjamina as affected by IBA treatments and beneficial microorganisms during the 2016 and 2017 seasons.

\begin{tabular}{|c|c|c|c|c|c|c|c|c|c|}
\hline \multirow{3}{*}{\multicolumn{2}{|c|}{$\begin{array}{c}\text { IBA } \\
\text { application methods } \\
\text { "ppm" }\end{array}$}} & \multicolumn{8}{|c|}{ Beneficial microorganisms } \\
\hline & & \multicolumn{4}{|c|}{ First season (2016) } & \multicolumn{4}{|c|}{ Second season (2017) } \\
\hline & & Cont. & Bacillus & AMF & Mean & Cont. & Bacillus & AMF & Mean \\
\hline \multicolumn{2}{|c|}{ Control (non-treated) } & 12.67 & 19.23 & 18.34 & 16.75 & 16.16 & 19.30 & 17.39 & 17.62 \\
\hline \multirow{2}{*}{ In the substrate } & 50 & 18.17 & 21.93 & 18.79 & 19.63 & 18.26 & 21.53 & 20.64 & 20.14 \\
\hline & 100 & 18.32 & 19.01 & 18.59 & 18.64 & 20.56 & 22.34 & 20.10 & 21.00 \\
\hline \multirow[b]{2}{*}{ By painting } & 1500 & 19.77 & 21.37 & 19.19 & 20.11 & 20.80 & 22.74 & 23.10 & 22.21 \\
\hline & 3000 & 19.58 & 23.40 & 19.38 & 20.79 & 20.24 & 24.93 & 24.53 & 23.23 \\
\hline \multirow[b]{2}{*}{ Talc paste } & 1500 & 20.20 & 21.38 & 20.52 & 20.70 & 20.03 & 21.73 & 21.78 & 21.18 \\
\hline & 3000 & 19.92 & 22.57 & 22.37 & 21.62 & 22.12 & 23.02 & 23.40 & 22.84 \\
\hline \multicolumn{2}{|l|}{ Mean } & 18.38 & 21.27 & 19.60 & & 19.74 & 22.23 & 21.56 & \\
\hline \multicolumn{2}{|l|}{ LSD at 0.05} & & & & & & & & \\
\hline \multicolumn{2}{|l|}{ IBA Treatments } & \multicolumn{4}{|c|}{0.92} & \multicolumn{4}{|c|}{0.74} \\
\hline \multirow{2}{*}{\multicolumn{2}{|c|}{ Microorganisms }} & \multirow{2}{*}{\multicolumn{4}{|c|}{0.63}} & \multirow{2}{*}{\multicolumn{4}{|c|}{0.51}} \\
\hline & & \multicolumn{2}{|c|}{1.67} & & & & & & 1.35 \\
\hline
\end{tabular}

Cont. $=$ control, AMF $=$ Arbuscular Mycorrhizal Fungi, Bacillus $=$ Bacillus subtilis 
Table 9. Total phenolics (mg GAE/ $\mathrm{g}$ DW) in tissue of girdled zone in Ficus benjamina as affected by IBA treatments and beneficial microorganisms during the 2016 and 2017 seasons.

\begin{tabular}{|c|c|c|c|c|c|c|c|c|c|}
\hline \multirow{3}{*}{\multicolumn{2}{|c|}{$\begin{array}{c}\text { IBA } \\
\text { application methods } \\
\text { "ppm" }\end{array}$}} & \multicolumn{8}{|c|}{ Beneficial microorganisms } \\
\hline & & \multicolumn{4}{|c|}{ First season (2016) } & \multicolumn{4}{|c|}{ Second season (2017) } \\
\hline & & Cont. & Bacillus & AMF & Mean & Cont. & Bacillus & AMF & Mean \\
\hline \multicolumn{2}{|c|}{ Control (non-treated) } & 8.93 & 11.47 & 10.80 & 10.40 & 9.43 & 13.27 & 10.80 & 11.17 \\
\hline \multirow{2}{*}{ in the substrate } & 50 & 9.54 & 12.67 & 11.67 & 11.29 & 11.53 & 14.97 & 14.63 & 13.71 \\
\hline & 100 & 9.40 & 13.50 & 12.88 & 11.93 & 14.63 & 16.67 & 14.28 & 15.19 \\
\hline \multirow{2}{*}{ by painting } & 1500 & 10.33 & 15.19 & 13.37 & 12.96 & 14.67 & 17.07 & 14.30 & 15.34 \\
\hline & 3000 & 14.30 & 19.10 & 17.57 & 16.99 & 16.13 & 19.20 & 19.90 & 18.41 \\
\hline \multirow{2}{*}{ Talc paste } & 1500 & 11.11 & 14.57 & 14.37 & 13.35 & 14.87 & 16.90 & 17.23 & 16.33 \\
\hline & 3000 & 14.10 & 17.87 & 16.03 & 16.00 & 15.30 & 17.77 & 16.33 & 16.47 \\
\hline \multirow{2}{*}{\multicolumn{2}{|c|}{$\begin{array}{l}\text { Mean } \\
\text { LSD at } 0.05\end{array}$}} & 11.10 & 14.91 & 13.81 & & 13.80 & 16.55 & 15.35 & \\
\hline & & & & & & & & & \\
\hline \multicolumn{2}{|l|}{ IBA Treatments } & \multicolumn{4}{|c|}{0.45} & \multicolumn{4}{|c|}{1.04} \\
\hline \multicolumn{2}{|l|}{ Microorganisms } & \multirow{2}{*}{\multicolumn{4}{|c|}{0.29}} & \multicolumn{4}{|c|}{0.68} \\
\hline \multicolumn{2}{|l|}{ Interaction } & & & & & \multicolumn{4}{|c|}{1.79} \\
\hline
\end{tabular}

\section{Promoters and inhibitors}

Data presented in Fig. 3 for the GC MS analysis of the samples extracted from basal portion root zone $(2.5-3.0 \mathrm{~cm})$ of the rooted layers for the control and the layers treated with IBA at 3000 ppm by painting girdled zone $+B$. subtilis which induced the highest effect upon rooting and survival percentages as well as root and vegetative growth characteristics, exhibited the presence of 3 phytohormones components in control and only 2 in the best treatment. The phytohormones components in the control sample were indole acetic acid and its derivatives at $8.54 \%$, zeatin at $0.28 \%$ and $\mathrm{GA}_{3}$ at $0.13 \%$. Meanwhile, the treatment of IBA at 3000 ppm by painting girdled zone + $B$. subtilis sample had indole acetic acid and its derivatives at $17.4 \%$ and zeatin at $0.26 \%$ as a percentage of total organic compounds per sample. The obtained results showed that the best treatment increased the concentration of IAA and its derivatives comparing to the control, which is strongly correlated with the im- provement in rooting and survival percentages as well as root and vegetative growth characteristics. This effect may be due to the role of combined treatment of IBA and $B$, subtilis in increasing the level of IAA at the girdled zone of $F$. banjamina airlayers. Thus, B. subtilis has the ability to produce plant growth regulators especially IAA which further play an important role in plant growth and root formation (Goto, 1990 and Rajan and Radhakrishna, 2013). Suresh et al. (2016), Ghosh et al. (2017) and Gilani et al. (2019) also reported that the response of air-layers to IBA with increasing concentration might be due to the activity of auxin and the accumulation of rooting co-factors at cambial region above the girdled zone, as well as enhancement of auxin concentration in the cell that may be adequate for initiating root primordia early by increasing cell division that further speed up callus formation. In addition, cytikinins and gibberellic acid have inhibitory effects on adventitious root formation as suggested by Pawlicki and We- 
lander (1992) and Brian et al. (1960) where gibberellic acid probably inhibited the outgrowth of root primordia. This could be related to a partial inhibition of endogenous starch synthesis in the plastids, as described by
Coleman and Greyson (1979). Also, Haissig (1972) concluded that $\mathrm{GA}_{3}$ hindered the development of root primordia via an inhibition of mitotic activity within the initiating root primordia.

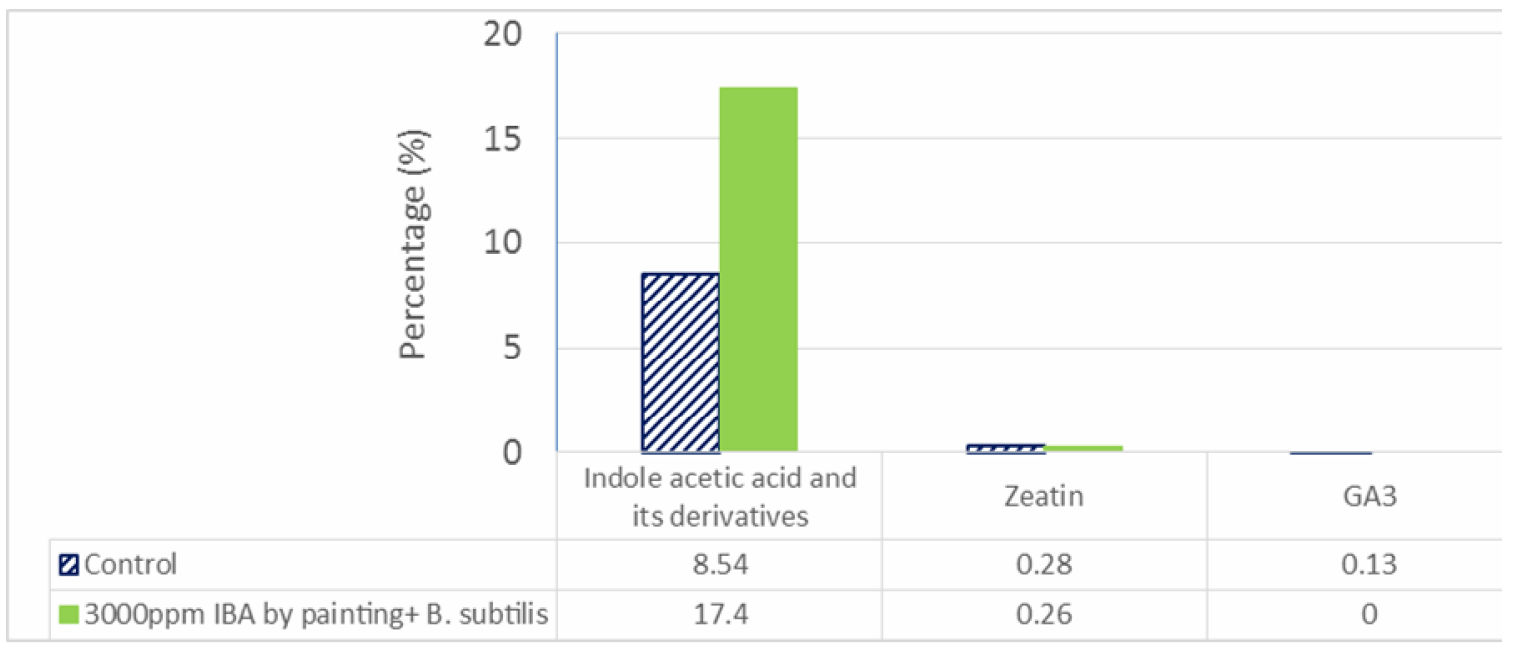

Fig 3. Gas chromatography-mass spectrometry (GC-MS) analysis of two samples extracted from root zone of Ficus benjamina layers treated with IBA at 3000 ppm by painting girdled zone $+B$. subtilis and the control.

\section{Conclusions}

From results obtained, it could be concluded that the better rooting and survival percentages of Ficus benjamina air-layers were observed under the treatment of $3000 \mathrm{ppm}$ IBA by painting girdled zone combined with B. subtilis, followed by 3000 ppm IBA by painting girdled zone + AMF for all root and growth characteristics before and after detachment of air-layers. Hence, this treatment is recommended for obtaining rooted layers from $F$. benjamina with superior root and vegetative growth characteristics in a short period of time as well as a high survival rate.

\section{References:}

Abdel-Rahman, S.S.A. and A.I. ElNaggar (2014). Promotion of rooting and growth of some types of Bougainvilleas cutting by plant growth promoting rhizobacteria (PGPR) and arbuscular mycorrhizal fungi (AMF) in combination with indole-3-butyric acid (IBA). Inter. J. Sci. and Res., 3(11): 97108.

Abdel-Rahman, S.S.A. and M. ElDsouky (2010). Effect of indole-3butyric acid (IBA) and Bacillus subtilis on rooting of Bougainvillea glabra var. sanderiana cuttings. The $5^{\text {th }}$ Scientific Conference for Agricultural Sciences, Fac. Agric. Assiut Univ. Oct. 1617, pp. 51-71.

Abdul Hakim, S.; M.K. Jaganath; S.M. Honnabyraiah; S.A. Kumar and K.J. Dayamani (2018). Influence of biofertilizer and auxin on growth and rooting of pomegranate (Punica granatum L.) cuttings. Int. J. Curr. Microbiol. Appl. Sci., 7(2): 1187-1193. 
Arslonov, M.N. (1979). Physiological changes occuring during root formation in lemon cuttings. Uzabekskii Biologicheskii Zhurnal, 5: 24-26.

Aslantas, R.; R .Cakmakci and F. Sahin (2007). Effect of plant growth promoting rhizobacteria on young apple trees growth and fruit yield under orchard conditions. Sci. Hort., 111(4): 371-377.

Baghel, M.; U.A. Raut and V. Ramteke (2016). Effect of IBA concentrations and time of air-layering in guava cv. L-49. Res. J. Agric. Sci., 7(1): 117-120.

Barea, J.M. and C. Azcon-Aguilar (1982). Production of plant growth regulating substances by the vesicular arbuscular mycorrhizal fungus Glomus mosseae. Appl. Envl. Micro., 43: 810-813.

Blythe, E.K.; J.L. Sibley; J.M. Ruter and K.M. Tilt (2004). Cutting propagation of foliage crops using a foliar application of auxin. Scientia Horticulturae, 103: 31-37.

Blythe. E.K.; J.L. Sibley; K.M. Tilt and J.M. Ruter (2007). Methods of Auxin Application in Cutting Propagation: A Review of 70 Years of Scientific Discovery and Commercial Practice. J. Environ. Hort., 25(3):166-185.

Brian, P.W.; H.G. Hemming and D. Lowe (1960). Inhibition of rooting of cuttings by gibberellic acid. Annals of Botany, N.S. 24(96): 407419.

Chauhan, V.B. (2009). Effect of special practices and different concentrations of indole butyric acid on rooting in air layering of fig (Ficus carica L.) cv. Poona under middle Gujarat conditions. M.Sc. Thesis, Anand Agriculture University, Anand (India).

Chawla, W. (2011). Studies on air layering, survival and growth of rooted layers in litchi (Litchi chinensis Sonn.). M.Sc. Thesis, Fac. Agric., Univ. Hort. and Fort., Nauni, Solan, India.

Chawla, W. and K. Mehta (2015). Effect of different growing media on survival and growth of transplanted litchi layers. The Asian J. Hort., 10(2): 257-261.

Coleman, W.K. and R.I. Greyson (1979). Analysis of root formation in leaf discs of Lycopersicon esculentum Mill cultured in vitro. Ann. Bot., 41: 307-320.

Das, B.K.; J.N. Das and G.C. Acharya (2006). Effect of potting media on air grafting of five sapota varieties. Orissa J. Hort., 34(2): 18-22.

Dessalegn, Y. and Y.N. Reddy (2003). Effects of different concentrations of auxins on rooting and root characters of air and ground layers of jojoba (Simmondsia chinensis (LINK.) C. K. Schneider). Ethiop. J. Sci., 26(2):155-159.

Erturk, Y.; S. Ercisli; A. Haznedar and R. Cakmakci (2010). Effects of plant growth promoting rhizobacteria (PGPR) on rooting and root growth of kiwifruit (Actinidia deliciosa) stem cuttings. Biol. Res., 43: 91-98.

Esitken, A.; S. Ercisli; D. Sevik and F. Sahin (2003). Effect of indole-3butyric acid and different strains of Agrobacterium rubi on adventive root formation from softwood and semi-hardwood wild sour cherry cuttings. Turkish J. Agric. and Fort., 27: 37-42.

Fales, F.W. (1951). The assimilation and degradation of carbohydrates by yeast cells. J. Bio. Chem., 193213.

Fernades, M.D.S. da S.; M.B. de Morais; F.F. Mesquita-Oliveira; C. Ulisses; J.F. de Medeiros and C.C. de Albuquerque (2019). Arbuscular mycorrhizal fungi and auxin associ- 
ated with microelements in the development of cuttings of Varronia leucocephala. Revista Brasileira de Engenharia Agrícola e Ambiental, 23(3): 167-174.

Fuscon, A. (2014). Regulation of root morphogenesis in arbuscular mycorrhizae: What role do fungal exudates, phosphate, sugars and hormones play in lateral root formation? Ann. Bot., 113: 19-33.

Gamlath, M.; K. Abeywickrama and S. Wickramarachchi (2010). Root growth promotion of Ficus species during air-layering. Cey. J. Sci. (Bio. Sci.), 39 (1): 45-51.

Ghosh, A.; K. Dey; A. Mani; F.K. Bauri and D.K. Mishra (2017). Efficacy of different levels of IBA and NAA on rooting of phalsa (Grewia asiatica L.) cuttings. Inter. J. Chem. Studies, 5(6): 567-571.

Gilani, S.A.Q.; K. Shah; I. Ahmed; A. Basit; M. Sajid; A.S. Bano; G. Ara and U. Shahid (2019). Influence of indole butyric acid (IBA) concentrations on air layerage in guava (Psidium guajava L.) cv. Sufeda. Pure Appl. Biol., 8(1): 355-362.

Gomez, K.A. and A.A. Gomez (1984). Statistical Procedures for Agricultural Research. $2^{\text {nd }}$ edn. John Wily, NY, 680 pp

Goto, M. (1990). Fundamentals of Bacterial Plant Pathology. Academic Press. Inc. San Diego, p. 339.

Hagen, R.H. (1990). A vegetative propagation of Cercidium, Parkinsonia and Prosopis species. M.Sc. Thesis, Fac. Agric., Dept. Pl. Sci., Univ. of Arizona.

Haissig, B.E. (1972). Meristematic activity during adventitious root primordium development. Plant Physiol., 49: 886-892.

Haissig, B.E. (1974): Metabolism during adventitious root primordium ini- tiation and development. New Zealand J. Fort. Sci., 4, 324-337.

Haissig, B.E. (1982). Carbohydrate and amino acid concentrations during adventitious root primordium development in Pinus banksiana Lamb. cuttings. Forest Sci., 28: 813-821.

Hartmann, H.T.; D.E. Kester; F.T. Davies and R.L. Geneve (2014). Hartmann and Kester's Plant Propagation: Principles and Practices, $8^{\text {th }}$ ed. Prentice Hall, New Jersey. pp. 395-399.

Hess, C.E. (1962). Characterization of the rooting co-factors extracted from Hedra helix L. and Hibiscus rosa-sinensis L. Proc. $16^{\text {th }}$ Int. Hort. Cong. pp. 382-388.

Hess, C.E. (1964). In regulators naturels de la croissance vegetables CNRS, Paris. pp. 517-527.

Karakurt, H.; R. Aslantas; G. Ozkan and M. Guleryuz (2009). Effects of indole-3-butyric acid (IBA), plant growth promoting rhizobacteria (PGPR) and carbohydrates on rooting of hardwood cutting of MM 106 Apple rootstock. Afri. J. Agric. Res., 4(2): 60-64.

Karunakara, J. (1997). Studies on induction of rooting in shoots of juvenile plants in guava (Psidium guajava L.). M.Sc. (Agri.) Thesis, Univ. Agric. Sci., Dharwad (India).

Kasem, M.M. and M.M. Abd El-Baset (2014). A comparative study to improve rooting of English lavender stems cuttings. Afri. J. Agric. Res., 9(50): 3632-3637.

Khalid, A.; M. Arshad and Z.A. Zahir (2004). Screening plant growthpromoting rhizobacteria for improving growth and yield of wheat. J. Appl. Micro., 96: 473-480.

Kumar, S. (2011). Layering in guava as influenced by growth regulators and Azospirillum. M.Sc. Thesis, 
Fac. Agric., Univ. Agric. Sci., Dharwad (India).

Maliauskas, G.; P.R. Venskutonis and T. A. Van Beek (2004). Screening of Radical Scavenging Activity of Some Medicinal and Aromatic Plants Extracts. Food Chem., 85: 231-237.

Maurya, R.K.; N.R. Ray; J.C. Chavda; V.B. Chauhan and A.K. Patil (2012). Evaluation of different organic media and water holding materials with IBA on rooting and survival of air layering in guava (Psidium guajava L.) cv. Allahabad Safeda. The Asian J. Hort., 7(1): 44-47.

Mitchell, R.J.; H.E. Garrett; G.S. Cox and A. Atalay (1986). Boron and ectomycorrhizal influences on indole-3-acetic acid levels and indole-3-acetic acid oxidase and peroxidase activities of Pinus echinata roots. Tree Physiol., 1:1-8.

Nanda, K.K. (1975). Physiology of adventitious root formation. Indian $\mathrm{J}$. Plant Physiol., 18: 80-90.

Nanda, K.K. and V.K. Kochhar (1985). Vegetative propagation of plants. Kalyani publishers. New Delhi, p. 234.

Noggle, G.R. and G.J. Fritz (1989). Introductory Plant Physiology. $2^{\text {nd }}$ ed. Publ. Prentice Hall of India, New Delhi.

Pandey, D. and R.K. Pathak (1981). Effect of Rootstocks, IBA and Phenolic Compounds on the Rooting of Apple Cuttings. Propagation Hort., 13: 105-110.

Patten, C.L. and B.R. Glick (2002). Role of Pseudomonas putida indole acetic acid in development of the host plant root system. Appl. Environ. Micro., 68: 3795-3801.

Pawlicki, N. and M. Welander (1992). The effects of benzyladenine and gibberellic acid on adventitious root formation in apple stem discs. Agron. Sci., 12(10): 783-788.

Puri, S. and R. Nagpal (1988). Effects of auxins on air layers of some agroforestry species. Indian J. Forst., 11(1): 28-32.

Rajan, S.A. and D. Radhakrishna (2013). Effect of entophytic bacteria on the rooting and establishment of cuttings of Hibiscus rosa sinensis. J. Agric. and Veter. Sci., 3(2): 17-21.

Reddy, P.P.N.; N.R. Ray; A.D. Patel and J.S. Patel (2014): Effect of rooting media and IBA (indole butyric acid) levels on rooting and survival of air layering in fig (Ficus carica L.) cv. POONA under middle Gujarat agro-climatic conditions. Theasian J. Hort., 9(1): 1-5.

Rinallo, C.; L. Mittempergher; G. Frugis and D. Marriott (1999). Clonal propagation in the genus Ulmus: Improvement of rooting ability by Agrobacterium rhizogenes T-DNA genes. J. Hort. Sci. and BioTech., 74(4): 500-506.

Rymbai, H. and G.S. Reddy (2010). Effect of IBA, time of layering and rooting media on air-layers and plantlets survival under different growing nursery condition in guava. Indian J. Hort., 67: 99-104.

Sarkar, A.; T. Asaeda; Q. Wang and M.H. Rashid (2015). Arbuscular mycorrhizal influences on growth, nutrient uptake and use efficiency of Miscanthus sacchariflorus growing on nutrient-deficient river bank soil. Flora-Morphol. Distrib. Funct. Ecol. Plants, 212: 46-54.

Scagel, C.F. (2001). Cultivar specific effects of mycorrhizal fungi on the rooting miniature rose cuttings. J. Environ. Hort., 19: 15-20.

Scagel, F.C.; K. Reddy and J.M. Armstrong (2003). Mycorrhizal fungi in rooting substrate influences the quantity and quality of roots on 
stem cuttings of hik's yew. HortTechnology, 13: 62-66.

Schott, K.M.; B.D. Pinno and S.M. Landhausser (2013). Premature shoot growth termination allows nutrient loading of seedlings with an indeterminate growth strategy. New Forst., 44: 635-647.

Singh, P.; J. Chandrakar; A.K. Singh; V. Jain and S. Agrawal (2007). Effect on rooting in guava cv. L-49 through PGR and organic media under Chhattisgarh condition. Acta Hort., (735): 197-200.

Solanki, K.R.; N.L. Kackar and S.K. Jindal (1986). Air layering in Prosopis cineraria L. Macbride. Indian Forester, 112(3): 202-207.

Suresh, K.; D. Thippesha and M. Ganapathi (2016). Effect of growth regulators on rooting of air-layers of rose apple (Syzigium jambos L.). Res. Environ. Life Sci., 9(10): 1229-1231.

Suryanarayana, V. and K.V. Rao (1984). Effect of growth regulators on air layering of fig and pomegranate. Andra Agric. J., 31: 54-58.

Tagwa, T. and J. Bonner (1957). Mechanical properties of the Avena coleoptile as related to auxin and to ionic interactions. Plant Physiol., 32: 207-212.

Udhavrao, T. N. (2017). Effect of different growth regulators on air layer- ing of pomegranate (Punica granatum L.) cv. Bhagwa. M.Sc. Thesis, Dept. Hort., Fac. Agric., Parhani Univ., Maharashtra (India).

Wells, R. (1986). Air layering: An alternative method for the propagation of Mahonia aquifolia 'Compacta'. Comb. Proc. Intl. Plant Prop. Soc., 36: 97-99.

Wiessman-Ben, Z. and Z. Tchoundejeu (2000). Vegetative tree propagation for arid and semi-arid land. http://www.cgiar.org/ICRAF/res.

Woodward, A.W. and B. Bartel (2005). Auxin: Regulation, Action and Interaction. Ann. Bot., 95: 707-735.

Yeboah, J.; B.K.B. Banful; P.Y. Boateng; F.M. Amoah; B.K. Maalekuu and S.T. Lowor (2014). Rooting response of air-layered shea (Vitellaria paradoxa) trees to media and hormonal application under two different climatic conditions. Amer. J. Plant Sci., 5: 12121219.

Zenginbal, H. and T. Demir (2018). Effects of some rhizobacteria and indole-3-butyic acid on rooting of black and white mulberry hardwood cuttings. J. Animal \& Plant Sci., 28(5): 1426-1431. 
تأثير ات المشتركة لإضافة الأكسين والكائنات الحية الاقيقة المفيدة على تجذير ونمو التراقيد

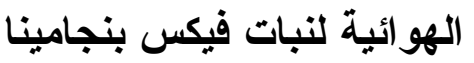

سيد شحاته عابدين عبدالرحمن، عمر حسنى محمد ابراهيم، جمال طه موسي وهاله بشير سليمان

قسم الزينة وتتسيق الحدائق - كلية الزراعة - جامعة أسيوط

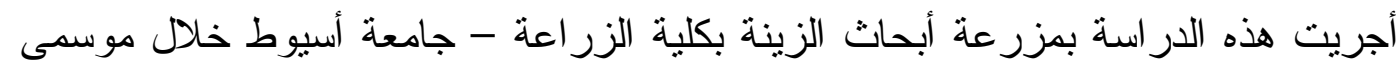

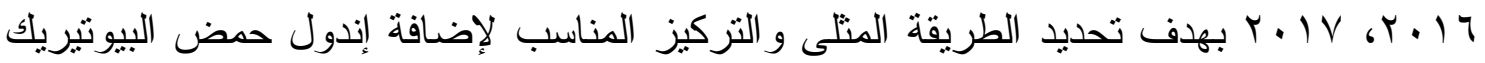

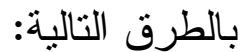

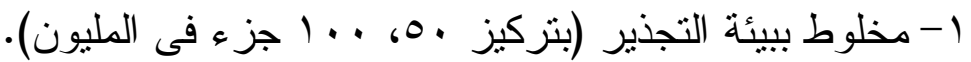

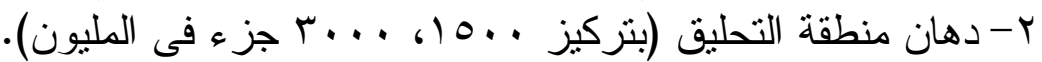

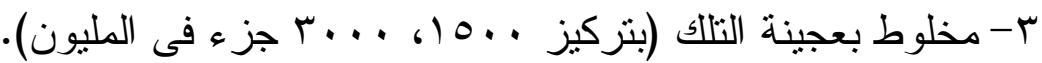

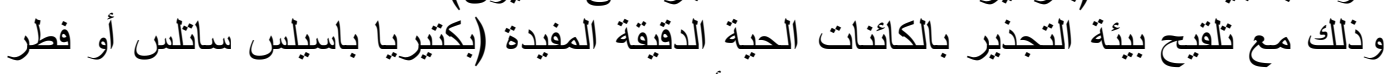

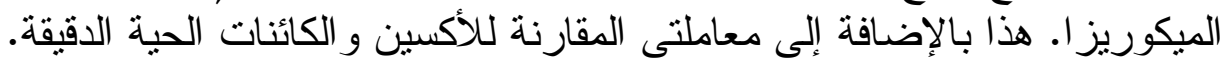

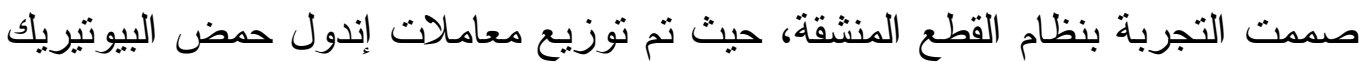

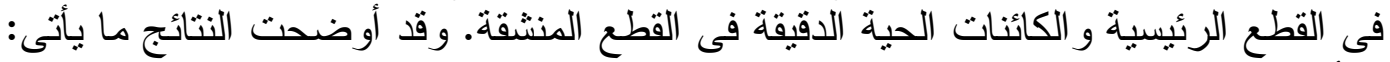

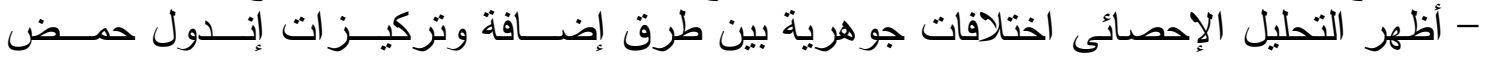
البيوتيريك مقارنة بالكنتزول.

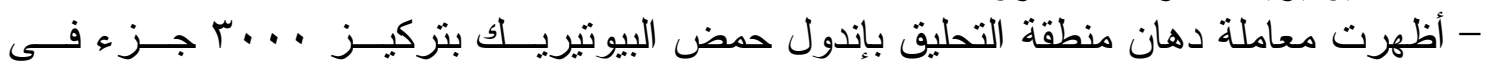

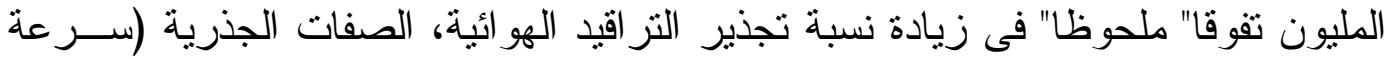

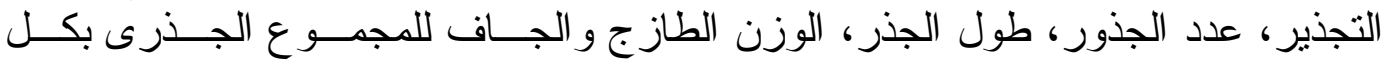
نز قيدة).

- اتضـح وجود ارتباط وثيق بين القدرة العالية على التجذير وزيــادة محتهـوى الأنـسجة مـــن

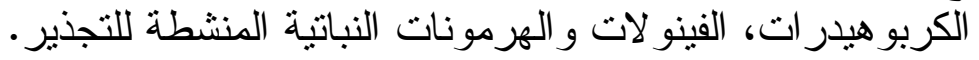

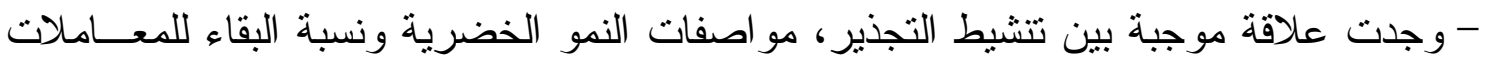

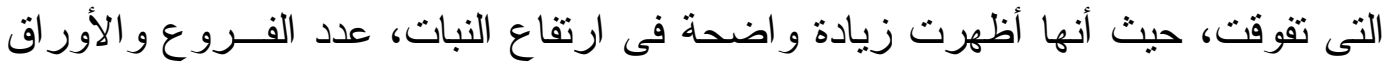

$$
\text { فى النباتات الجديدة. }
$$

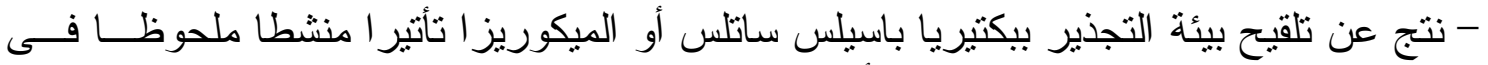

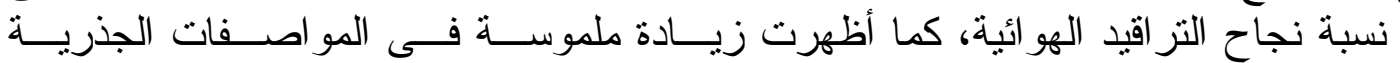

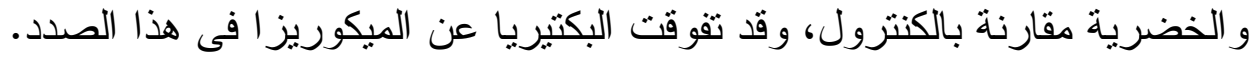

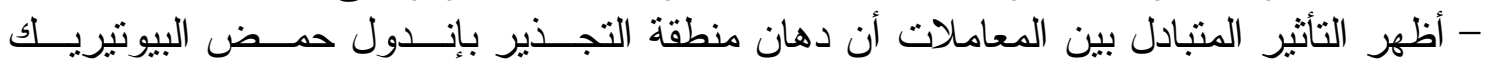

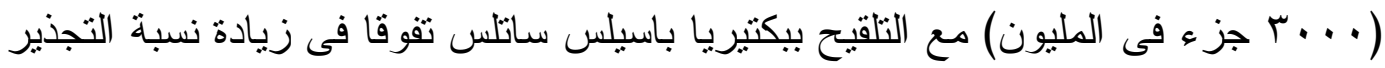

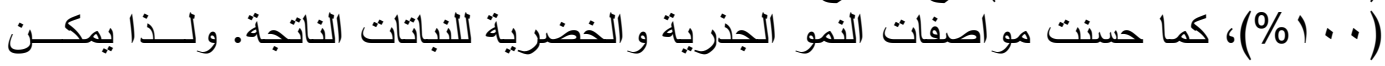
النصح بتطبيق هذه المعاملة عند إكثار نبات فيكس بنجامينا بالترقيد الهو ائى بهدف الإنتاج 